\title{
Turizm Gelirlerinin Ekonomik Büyümeye Etkisi: Türkiye İçin Yapısal Kırılmalı Birim Kök ve Eşbütünleşme Analizi
}

\author{
Hasan Önder Sarıdoğan ${ }^{1}$
}

Turizm Gelirlerinin Ekonomik Büyümeye Etkisi: Türkiye İçin Yapısal Kırılmalı Birim Kök ve Eşbütünleşme Analizi

\section{Öz}

Turizm sektörü yirminci yüzyılın ikinci yarısından itibaren dünya ekonomisinin en hızı gelişen ve genişleyen sektörlerinden biri haline gelmiştir. Turizm, döviz kazandırıcı etkisinin yanı sıra milli gelire, istihdama ve ödemeler dengesine olan önemli katkılarıyla ülke ekonomileri açısından alternatif bir büyüme kaynağıdır. Sektör çok yönlü özelliği ile sadece ekonomiyi değil aynı zamanda sosyal ve kültürel hayatı da etkilemektedir. Özellikle Türkiye'nin de içinde bulunduğu gelişmekte olan ülkeler açısından turizm, bir kalkınma faktörü olarak son derece önemli bir yere sahiptir. Bu çalışmanın amacı, Türkiye'nin 1987-2018 dönemi verilerini kullanarak uluslararası turizm gelirleri ile ekonomik performans arasındaki ilişkiyi incelemektir. Bu amaçla yapısal kırılmalı birim kök ve eşbütünleşme testleri kullanılmıştır. Eşbütünleşme testi sonuçlarına göre seriler arasında eşbütünleşme ilişkisi görülmektedir. Uzun vadeli tahmin sonuçlarına göre, turizm gelirlerinin ekonomik performans üzerinde pozitif bir etkisi vardır. Hata düzeltme modelinin sonuçlarına göre turizm değişkeni ile diğer tüm değişkenler arasında anlamlı bir ilişki tespit edilmiştir. Dolayısıyla kısa ve uzun dönem tahmin sonuçlarına göre turizm gelirleri ekonomik büyüme üzerinde önemli bir etkiye sahiptir.

Anahtar Kelimeler: Turizm, Ekonomik Performans, ARDL Model

\section{Giriş}

Turizm dünyanın en hızlı büyüyen sektörlerinden biri olarak küresel ölçekte etkiler bırakan sosyo-ekonomik bir güç olarak kabul edilmiştir. Günümüzde turizm hareketleri ekonomik gelişmenin bir parçası olarak kabul edilmekte ve yıllar geçtikçe artan sayıda ülke turizm yatırımlarına önem vermektedir. Bu durum, turizmi kalkınma adına kilit bir faktör haline getirmiştir. 21. yüzyılın başlarından itibaren turizm sektörünün hacmi petrol ihracatı, gıda ürünleri veya otomotiv sektörü hacmine eşit ve hatta bu sektörleri geçer durumdadır. Turizm, uluslararası ticaretin en önemli unsurlarından birisi olmakla beraber gelişmekte olan birçok ülke için de ana gelir kaynaklarından birini temsil etmektedir (UNWTO, 2019).

\footnotetext{
1 Öğr. Gör. Dr., Akdeniz Üniversitesi Kumluca Meslek Yüksekokulu, Muhasebe ve Vergi Bölümü, ondersaridogan@akdeniz.edu.tr, Yazar ORCID bilgisi: http://orcid.org/0000-0002-6463-4681
}

The Impacts of Tourism Revenues on Economic Growth: for Turkey

Tourism sector has become one of the rapidly developing cond the foreign exchange-earning effect, tourism is an alternative source of growth for national economies with its significant contributions to national income, employment and the sector affects not only the economy but also the social and cultural life. Tourism is very important as a development factor in particular for developing countries relationship between international tourism revenues and economic performance, using data from Turkey 1987With this purpose, structural break unit root and cointegration tests was used. Cointegration relation test results. According to the long-term estimation results, tourism revenues have a positive impact on economic performance. According to the results of the error between tourism and all other variables. Therefore, according to the both short and long short run estimation results, tourism revenues have a significant impact on Keywords: Tourism, Economic Performance, ARDL Model Unit Root and Cointegration Tests with Structural Break

gan@akdeniz.edu.tr, Yazar ORCID bilgisi: http:/orcid.org/0000-0002-6463-4681 
Turizm sektörünün ekonomik açıdan öne çıkmasının nedenlerinden birisi de birçok alt hizmeti bünyesinde barındırmasıdır. Konaklama, gezi, ulaştırma, yiyecek ve içecek, seyahat acenteleri, tur şirketleri, el sanatları, hediyelik eşya üretimi gibi çok sayıda alt sektörü etkilemesi turizmin önemini artırmaktadır. Turizm faaliyetleri sonucu üretilen mal ve hizmetler genellikle bulundukları yerde tüketildiklerinden bulunduğu yörenin ekonomisine hareketlilik kazandırmaktadır.

Turizm sadece ekonomik açıdan değerlendirilemeyecek kadar geniş bir etki alanına sahiptir. Sosyal, kültürel ve siyasal alanda ülke içi ve uluslararası ilişkilerde belirleyici sonuçları olan bir sektördür. Turizm, mal ve hizmet ihracatı açısından istenilen düzeye ulaşamamış ülkelerin en önemli döviz kaynakları arasında yer almaktadır. Ayrıca istihdamın artırılması, kişi başına gelirin yükseltilmesi, bütçe açıklarının kapatılması gibi iktisadi faydaları vardır.

Çalışmanın temel amacı dünyanın en önemli destinasyonları arasında yer alan Türkiye'nin turizm gelirleri ile ekonomik performansı arasındaki ilişkiyi incelemektir. Bu bağlamda, Türkiye'nin 1987-2018 dönemi verileri kullanılarak turizm sektörünün ekonomik performans üzerindeki etkisi araştırılmıştır. Çalışmada diğer çalışmalardan farklı olarak turizm gelirleri yanı sıra klasik üretim fonksiyonun temel girdileri olan emek ve sermayeyi temsil eden kontrol değişkenler modele eklenerek analiz genişletilmiştir. Ayrıca yapılan her güncel çalışma Türkiye'deki turizm sektörünün gelişimini takip edebilme ve geçmiş yıllar ile karşılaştırma yapabilme olanağı sağlamaktadır. Bu açıdan literatüre katkı sağlayacağı düşünülmektedir.

Çalışmada öncelikli olarak dünyada ve Türkiye'de turizm sektörünün gelişimi incelenmiştir. Sonrasında konu ile ilgili yapılan çalışmalara ait literatür özetlenmiştir. Son bölümde ise ampirik analiz ile ilgili veri seti, model ve metodoloji tanıtılarak uygulanan test sonuçları sunulmuştur.

\section{Dünyada ve Türkiye'de Turizm Faaliyetlerinin Gelişimi}

Turizm sektörü, Endüstri Devrimi ile birlikte değişim gösteren sosyal, kültürel ve ekonomik aktiviteler ile çok yakın bir ilişki içinde ilerleme göstermiştir. Endüstri devrimi, tüm diğer sektörlerde olduğu gibi turizm sektörünün de gelişmesinde önemli bir paya sahiptir. Ücretli izin hakkı, insanların boş zamanının artması, teknolojik gelişmeler, eğitim ve kültür seviyesinin artması, seyahat özgürlüğü ve turizm bilincinin gelişmesi, gelir ve refah seviyesinin artması, ulaştırma sektöründe gelişmeler ve sosyal güvenlik düzenlemeleri gibi günlük hayatı etkileyen unsurlar endüstri devriminin turizm sektörüne katkı yaptığı başlıca konulardır (Kozak, 2012: 46).

Dünyada modern anlamda turizm faaliyetleri İkinci Dünya Savaşı sonrası ortaya çıkmıştır. Özellikle ulusal ve uluslararası havayolu ulaşımında yaşanan yenilikler, destekleyici bir güç olarak turizmin günümüzdeki içerik ve boyutlara ulaşması sağlamıştır. Başka bir deyişle, turizm sektörü ulaşım ve iletişim teknolojisindeki gelişim ile hemen aynı değerde etkilenmiş ve köklü bir değişime uğramıştır. Ayrıca turizm ile ilgili mal ve hizmetlerin sunumları da kitlesel üretime konu olan her mal ve hizmet gibi, özgün reklam ve tanıtım teknikleri aracılığı ile iç-dış pazarlara ulaştırılabilir hale gelmiştir (Eralp, 1983: 14-15).

Tablo 1'de İkinci Dünya Savaşı sonrası dünyadaki uluslararası turist sayılarına kıtalar bazında yer verilmiştir.

Tablo 1'de görüleceği üzere, 1950-2000 yılları arasında uluslararası turist hareketlerinin yoğunlaştığı bölgeler Avrupa ve Amerika kıtalarıdır. Sonraki dönemde ise Asya-Pasifik bölgesinin Avrupa'dan sonra ikinci önemli hareket noktası haline geldiği görülmektedir. İkinci Dünya 
Savaşı sonrası dünya genelinde uluslararası turist sayısı, Orta Doğu bölgesi hariç sürekli artış yaşamıştır. 1960-1965 dönemini kapsayan ve 1967 yılında yaşanan Arap-İsrail savaşı OrtaDoğu'da yaşanan turist sayısı azalışının en önemli sebepleri arasında yer almaktadır. Dünya genelinde 1950 yılında 25,3 milyon uluslararası turist ziyareti gerçekleşirken, bu rakam 2017 yılında 1,3 milyara ulaşmıştır.

Tablo 1: 1950-2017 Dünya Uluslararası Turist Sayısı

\begin{tabular}{c|cccccc}
\hline Yıllar & Dünya & Avrupa & Amerika & Afrika & Asya-Pasifik & Orta Doğu \\
\hline 1950 & 25,3 & 16,8 & 7,5 & 0,5 & 0,2 & 0,2 \\
1960 & 69,3 & 50,4 & 16,7 & 0,8 & 0,9 & 0,6 \\
1965 & 112,9 & 83,7 & 23,2 & 1,4 & 2,1 & 2,4 \\
1970 & 165,8 & 113 & 42,3 & 2,4 & 6,2 & 1,9 \\
1975 & 222,3 & 153,9 & 50 & 4,7 & 10,2 & 3,5 \\
1980 & 278,1 & 178,5 & 62,3 & 7,2 & 23 & 7,1 \\
1985 & 320,1 & 204,3 & 65,1 & 9,7 & 32,9 & 8,1 \\
1990 & 439,5 & 265,6 & 92,8 & 15,2 & 56,2 & 9,6 \\
1995 & 540,6 & 315 & 109 & 18.7 & 82 & 12,7 \\
2000 & 687 & 395,9 & 128,2 & 26.2 & 110,4 & 22,4 \\
2005 & 809 & 452.7 & 133.3 & 34.8 & 154.1 & 33.7 \\
2010 & 952 & 487.7 & 150.4 & 50.4 & 208.2 & 55.4 \\
2015 & 1,195 & 605.1 & 194.1 & 53.6 & 284.1 & 58.1 \\
2017 & 1,326 & 671.7 & 210.9 & 62.7 & 323.1 & 58.1 \\
\hline
\end{tabular}

Kaynak: 1950-1990: Tourism Market Trends, 2006 Edition, 1995-2017: UNWTO Tourism Highlights, 2018 Edition

Şekil 1'de 2017 yılı itibariyle dünya genelinde en çok turizm geliri elde eden ve en çok ziyaretçi ağırlayan ülkeler görülmektedir.

Şekil 1: 2017 Yılı Ülkeler Bazında Turist Sayısı ve Turizm Gelirleri

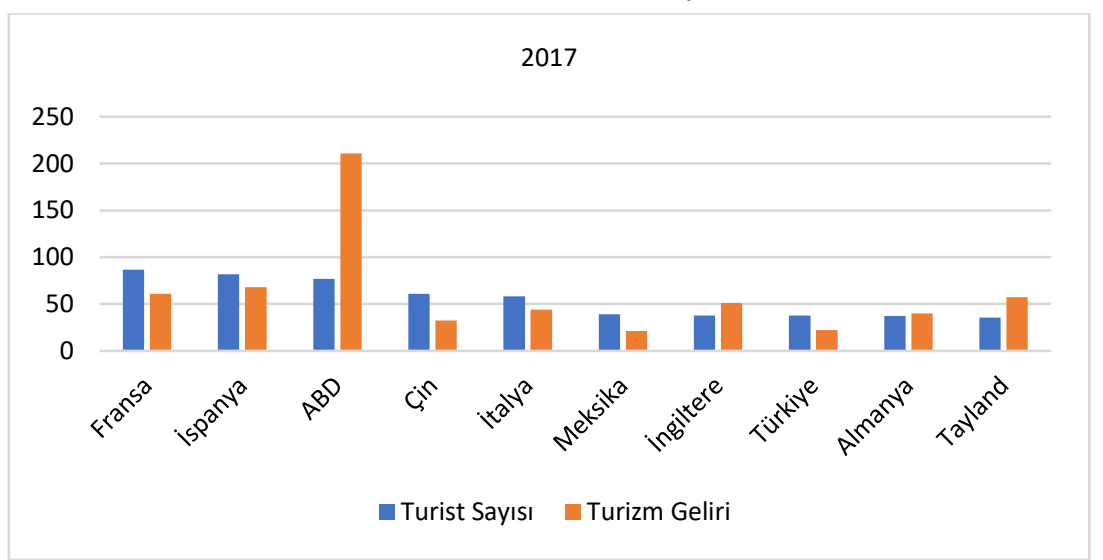

Kaynak: UNWTO Tourism Highlights, 2018 Edition

2017 yılında dünyada en çok uluslararası turist ağırlayan ülke 86,9 milyon ile Fransa'dır. Fransa'yı 81,8 milyon ile İspanya ve 76,9 milyon ile ABD takip etmektedir. Türkiye aynı yıl 37,6 milyon uluslararası turist sayısı ile dünyada sekizinci sırada yer almaktadır. Uluslararası turizm gelirlerine bakıldığında ise uluslararası turist sayısında üçüncü sırada yer alan ABD’nin yaklaşık 211 milyar dolar ile ilk sırada yer aldığı görülmektedir. Ayrıca ABD’nin yanı sıra Tayland, İngiltere ve Almanya uluslararası ziyaretçi sayısından daha fazla gelir elde eden ülkelerdir. Bu du- 
rum ülkeye gelen turistlerin büyük bir bölümünün gelir düzeyi yüksek turistlerden oluştuğunu göstermektedir.

Dünya Turizm Örgütü'nün "Tourism Towards 2030" adlı çalışmasındaki öngörülerine göre önümüzdeki on bir yıl boyunca uluslararası turizm, daha yavaş bir hızda olmakla birlikte artmaya devam edecek ve uluslararası turist hareketleri yılda ortalama 43 milyon artarak 2030 'da 1,8 milyara ulaşacaktır. Bu öngörülere göre turizm sektörü 21 . yüzyılın en büyük sektörlerinden birisi olarak ülkelerin ekonomik büyümelerine önemli katkıda bulunacaktır.

Türkiye'nin coğrafi açıdan doğu ile batı uygarlığının kesiştiği bir yerde bulunması turizm sektörü açısından avantajlı bir konumda olmasını sağlamaktadır. Geniş bir kültürel ve tarihi mirasa sahip olan Türkiye, doğal güzellikleriyle birlikte değerlendirildiğinde, turizm potansiyeli bakımından dünyanın en önemli destinasyonlarından biri durumundadır. Turizm, Türkiye gibi yıllardır cari açık veren ülke ekonomilerine milyarlarca dolar kaynak sağlayan en önemli sektörlerden birisidir.

Şekil 2'de Türkiye'ye gelen yabancı vatandaşların sayısı ve ülkede bıraktığı döviz gelirinin 2001-2018 dönemindeki seyri görülebilmektedir.

\section{Şekil 2: Türkiye Turizm Geliri ve Turist Sayısı Grafiği}

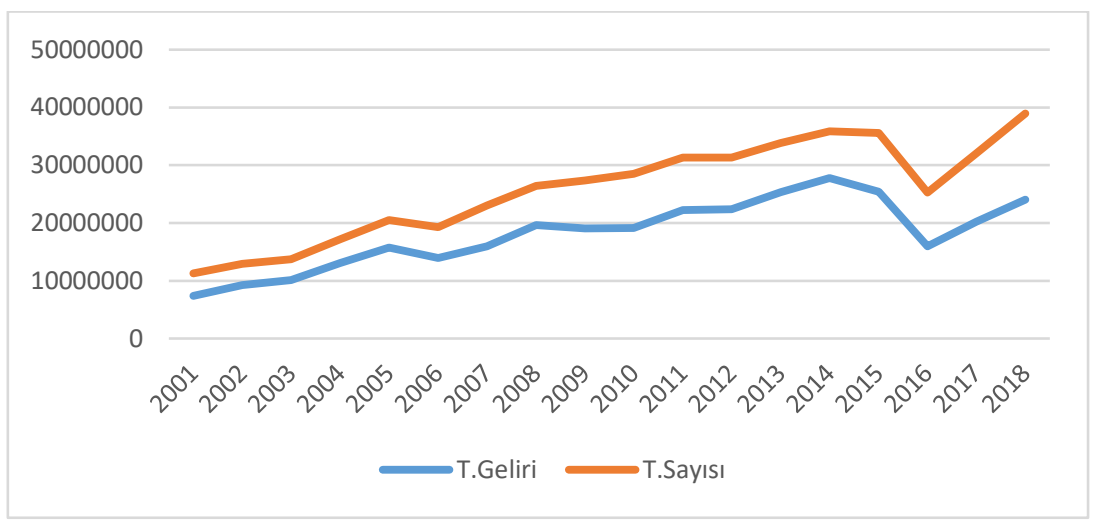

Kaynak: TUik, Turizm Geliri, Gideri ve Ortalama Geceleme Sayısı, 2001 - 2019, Çıkış Yapan Yabancı ziyaretçilerden elde edilen gelir.

Türkiye'ye gelen turist sayısı 2001 yılında yaklaşık 11 milyon kişi iken bu sayı 2018 yılında \%245 artarak yaklaşık 39 milyon kişiye ulaşmıştır. 2001 yılında yaklaşık 7 milyar dolar olan turizm geliri ise 2018 yılında \%225 artarak 24 milyar dolara çıkmıştır. Turizm sektörünün 2004 yılında yaşanan kuş gribi salgını ve 2015 yılında Rusya ile yaşanan uçak krizi hariç diğer yıllarda genel olarak pozitif bir ivme yakaladığı söylenebilmektedir.

Tablo 2'de Türkiye'de turizm gelirlerinin ihracat ve GSYH içindeki payları görülmektedir. Tablo 2'deki oranlar incelendiğinde turizm gelirlerinin ihracat gelirleri içindeki payının dalgalı bir seyir izlediği görülebilecektir. 2003 yılında turizm gelirlerinin ihracat gelirleri içindeki payı \%23 iken 2018 yılında \%17,5’e düşmüştür. Bu durumun mevsimsel ve iktisadi faktörlere bağlı olarak turizm gelirleri ve ihracat düzeyindeki farklı artış ya da azalış oranlarından kaynaklandığı düşünülmektedir. Ancak her dönemde turizm gelirlerinin dış ticarette önemli bir yer tuttuğu söylenebilir. Türkiye'de Turizm gelirlerinin GSYH'sindeki payı, incelenen dönemde \%2,6 ile $\% 4,4$ arasında değişmektedir. 
Tablo 2: Turizm Gelirlerinin ihracat Gelirleri ve GSYH Içindeki Oranı

\begin{tabular}{l|llcc}
\hline Yıllar & $\begin{array}{l}\text { ihracat } \\
(1.000 .000 \$)\end{array}$ & $\begin{array}{l}\text { Turizm } \\
\text { Gelirleri } \\
(1000 \$)\end{array}$ & $\begin{array}{c}\text { Turizm Gelirlerinin } \\
\text { ihracat Gelirleri } \\
\text { içindeki Payı (\%) }\end{array}$ & $\begin{array}{c}\text { Turizm Gelirinin } \\
\text { GSYH Içindeki Payı (\%) }\end{array}$ \\
\hline 2003 & 47252.8 & 13854.9 & 29.3 & 4.4 \\
2004 & 63167.0 & 17076.6 & 27.0 & 4.2 \\
2005 & 73476.4 & 20322.1 & 27.7 & 4.1 \\
2006 & 85534.7 & 18594.0 & 21.7 & 3.4 \\
2007 & 107271.8 & 20942.5 & 19.5 & 3.1 \\
2008 & 132027.2 & 25415.1 & 19.2 & 3.3 \\
2009 & 102142.6 & 25064.5 & 24.5 & 3.9 \\
2010 & 113883.2 & 24931.0 & 21.9 & 3.2 \\
2011 & 134906.9 & 28115.7 & 20.8 & 3.4 \\
2012 & 152478.5 & 29351.4 & 19.2 & 3.3 \\
2013 & 157610.2 & 34305.9 & 21.3 & 3.4 \\
2014 & 151802.6 & 32309.0 & 21.8 & 3.7 \\
2015 & 143934.9 & 31464.8 & 21.9 & 3.7 \\
2016 & 142606,2 & 22107,4 & 15.5 & 2.6 \\
2017 & 156992,9 & 26283,6 & 16.7 & 3.1 \\
2018 & 167967,2 & 29512,9 & 17.5 & 3.8 \\
\hline
\end{tabular}

Kaynak: Kültür ve Turizm Bakanlığı

\section{Literatür}

Literatürde turizm sektörünün ekonomik etkilerini araştıran çok sayıda teorik ve ampirik çalışma mevcuttur. Çalışmaların sonuçları dört temel hipotez çerçevesinde şekillenmiştir (Chatziantoniou vd. 2013, Antonakakis vd. 2015). Bu hipotezlerden ilki turizm sektöründen ekonomik büyümeye doğru tek yönlü nedensellik ilişkisinin olduğunu ileri süren "turizme dayalı büyüme hipotezi" (TLEG), ikinci hipotez ekonomik değişimlerden turizm sektörüne doğru tek yönlü nedensellik ilişkisinin olduğunu öne süren "ekonomi odaklı turizm hipotezi" (EDTG), üçüncü hipotez turizm ve ekonomik büyüme arasında karşılıklı nedensellik ilişkisinin olduğunu iddia eden "geri bildirim hipotezi" ve dördüncü hipotez turizm hareketleri ile ekonomik gelişim arasında herhangi bir nedensellik ilişkisinin bulunmadığını ileri süren hipotezdir. Aşağıda Tablo 3'te bu hipotezleri destekleyen çalışmalara ait bir özet sunulmuştur. 
Tablo 3: Literatür Özeti

\begin{tabular}{|c|c|c|}
\hline $\begin{array}{c}\text { Turizme dayalı büyüme hipotezi (TLEG) } \\
\text { Turizm } \rightarrow \text { Büyüme }\end{array}$ & $\begin{array}{l}\text { Balaguer \& Jorda (2002) } \\
\text { Sugiyarto vd. (2003) } \\
\text { Durbarry (2004) } \\
\text { Croes \& Vanegas (2008) } \\
\text { Proenca \& Soukiazis (2008) } \\
\text { Fayissa vd. (2011) }\end{array}$ & $\begin{array}{l}\text { Dritsakis (2012) } \\
\text { Eeckels vd. (2012) } \\
\text { Ivanov \& Webster (2013) } \\
\text { Surugiu \& Surugiu (2013) } \\
\text { Brida vd. (2016). }\end{array}$ \\
\hline $\begin{array}{c}\text { Ekonomi odaklı turizm hipotezi (EDTG) } \\
\text { Büyüme } \rightarrow \text { Turizm }\end{array}$ & $\begin{array}{l}\text { Narayan (2004) } \\
\text { Oh (2005) } \\
\text { Payne \& Mervar (2010) }\end{array}$ & Tang (2011) \\
\hline $\begin{array}{c}\text { Geri bildirim-feedback hipotezi } \\
\text { Büyüme } \leftrightarrow \text { Turizm }\end{array}$ & $\begin{array}{l}\text { Dritsakis (2004) } \\
\text { Ongan \& Demiröz (2005) } \\
\text { Lee \& Chang (2008) } \\
\text { Chen \& Chiou-Wei (2009) } \\
\text { Cortés-Jiménez vd. (2009) } \\
\text { Seetanah (2011) }\end{array}$ & $\begin{array}{l}\text { Kasimati (2011) } \\
\text { Apergis \& Payne (2012) } \\
\text { Tuğcu (2014) } \\
\text { Khoshnevis Yazdi vd. } \\
\text { (2017). }\end{array}$ \\
\hline $\begin{array}{c}\text { İki değişken arasında herhangi bir ilişkinin } \\
\text { olmadığını ileri süren hipotez } \\
\text { Büyüme } \neq \text { Turizm }\end{array}$ & $\begin{array}{l}\text { E. Martin \& Morales (2004) } \\
\text { Katırcıoğlu (2009) }\end{array}$ & $\begin{array}{l}\text { Po \& Huang (2008) } \\
\text { Tang \& Jang (2009) } \\
\text { Yavuz (2006) }\end{array}$ \\
\hline
\end{tabular}

Bu çalışmada "turizme dayalı büyüme hipotezi" (TLEG) Türkiye açısından incelenmiş ve Türkiye'nin turizm gelirlerinin ekonomik etkileri analiz edildiğinden öncelikli olarak Türkiye üzerine yapılan çalışmalara yer verilmiştir.

\subsection{Ulusal Literatür}

Yıldırım ve Öcal (2004), 1962-2002 döneminde Türkiye'de turizm gelirlerinin ekonomik büyüme üzerindeki etkilerini VAR analizi çerçevesinde incelemiştir. Ampirik bulgular, uzun vadede turizm gelirlerinin büyümeyi teşvik edici etkilerinin olmasına rağmen, turizm ile iktisadi gelişim arasında kısa vadeli bir ilişki olmadığını göstermektedir.

Gündüz ve Hatemi-J (2005), turizm ve ekonomik büyüme arasındaki ilişkiyi Kaldıraçlı Bootstrap nedensellik testinden yararlanarak araştırmıştır. Araştırma sonuçlarına göre, Türkiye'de turizm öncülüğünde büyüme hipotezinin ampirik olarak desteklendiği tespit edilmiştir.

Ongan ve Demiröz (2005), 1980-2004 yılları için uluslararası turizm gelirlerinin Türkiye'nin uzun vadeli ekonomik büyümesi üzerindeki etkisini ampirik olarak incelemiştir. Çeyrek dönemlik verilerin kullanıldığı çalışmada, turizm kaynaklı büyüme hipotezi Johansen eşbütünleşme ve Granger nedensellik testi kullanılarak test edilmiştir. Ampirik sonuçlar kısa ve uzun vadede değişkenler arasında iki yönlü nedensel ilişkilerin olduğunu göstermiştir. Başka bir deyişle, ekonomik büyümenin turizmin sektörel gelişimine katkıda bulunduğu, turizmin ise ekonomik büyümeye pozitif katkı yaptığı tespit edilmiştir.

Bahar (2006), 1963-2004 döneminde turizm gelirleri ile milli gelir arasındaki ilişkileri araştırmıştır. VAR modelinin kullanıldığı çalışmada ampirik olarak turizmin ekonomik büyümeyi pozitif etkilediği ispatlanmıştır. Yapılan eş bütünleşme testine göre de uzun dönemde turizm gelirleri ile ulusal gelir arasında çift taraflı nedensellik ilişkisi tespit edilmiştir. 
Çetintaş ve Bektaş (2008), Türkiye'nin 1964-2006 dönemi turizm harcamalarının iktisadi büyüme üzerindeki etkilerini araştıran bir çalışma yayımlamışlardır. Çalışmada kullanılan gayri safi yurtiçi hasıla ve turizm geliri serileri TÜFE $(2000=100)$ endeksi kullanılarak reel hale dönüştürülmüştür. Ardından gerçekleştirilen ARDL sınır testi yaklaşımı sonuçlarına göre, reel turizm gelirleri ile reel gayri safi yurtiçi hasıla arasında kısa dönemli bir ilişkiye rastlanamamıştır. Ancak uzun dönemli analize göre, turizm gelirlerinin milli gelirin önemli bir belirleyicisi olduğu tespit edilmiştir.

Kızılgöl ve Erbaykal (2008), turizmden elde edilen gelir ile gayri safi yurt içi hasıla arasındaki ilişkiyi Toda-Yamamoto nedensellik analizi kullanarak incelemiştir. Çalışmada Türkiye'nin 1992-2006 yıllarına ait çeyrek dönemlik verileri kullanılmıştır. Analiz sonuçlarına göre, gayri safi yurt içi hasıladan turizm gelirlerine doğru tek taraflı bir nedensellik tespit edilmiştir.

Işık (2010) çalışmasında Türkiye'nin uluslararası turizm gelirleri ile ülkeye gelen yabancı ziyaretçi harcamaları ilişkisini 1970-2008 dönemi verilerini kullanarak araştırmıştır. Çalışmada Augmented Dickey-Fuller durağanlık testi ile Johansen Eş-bütünleşme ve Granger Nedensellik analizleri yapılmıştır. Sonuçlara göre, uzun dönemde uluslararası turizm gelirleri ile uluslararası turist harcamaları arasında karşılıklı nedensellik ilişkisinin olduğu tespit edilmiştir.

Hepaktan ve Çınar (2010), Türkiye'nin 1980-2008 dönemine ait yabancı ziyaretçi sayısı, turizmden elde edilen net gelirler, dış ödemeler dengesi ve sabit fiyatlarla GSMH büyümesi verileri ile bir analiz gerçekleştirmiştir. Analiz sonuçlarında, turizm gelirleri ve yabancı ziyaretçi sayılarının dış ticaret dengesini etkilediğini ancak gayri safi milli hasılayı doğrudan etkilemediği belirtilmiştir. Bununla birlikte, turizm sektörünün istihdam ve üretim artışı nedeniyle dolaylı yoldan bazı sonuçlarının olduğu üzerinde durulmuştur.

Yavuz (2006), 1992Q1- 2004Q4 döneminde Türkiye'nin turizm geliri artışının büyüme üzerindeki etkisini araştırmaya yönelik bir çalışma gerçekleştirmiştir. Çalışmada Augmented Dickey-Fuller durağanlık testi ve Zivot-Andrews'in yapısal kırılmayı ölçen durağanlık testi kullanılmıştır. Ayrıca Toda-Yamamoto ve standart Granger nedensellik analizi kullanılarak, nedensellik ilişkisi araştırılmıştır. Araştırma sonuçlarına göre, her iki nedensellik testi de turizmden elde edilen gelir ile iktisadi büyüme arasında nedensellik ilişkisi tespit edememiştir.

Polat ve Günay (2012), 1969-2009 döneminde Türkiye'nin ihracat gelirleri ile turizm gelirlerinin iktisadi büyüme üzerindeki etkilerini araştırmıştır. Bu amaçla ihracat gelirleri, turizm gelirleri ve GSMH değişkenlerini kullanılmıştır. Johansen eş bütünleşme testi sonuçlarına göre, ihracat sonucu elde edilen gelirler, uluslararası turizmden elde edilen gelirler ve iktisadi büyümenin uzun dönemde eşbütünleşik olduğu belirlenmiştir. Bununla birlikte, kısa dönem analiz sonuçlarına göre hem ihracat gelirleri hem de turizm gelirlerinden iktisadi büyümeye doğru tek yönlü bir nedensellik bulgusuna rastlanılmıştır.

Kızılkaya vd. (2016), Türkiye'de 1980-2014 döneminde yabancı ziyaretçi sayısı, yabancı ziyaretçilerden elde edilen gelir ve iktisadi büyüme arasındaki ilişkileri incelemiştir. Çalışmada, ARDL sınır testi kullanılmış olup kısa ve uzun dönem eş bütünleşme katsayıları tahmin edilmiştir. Analiz sonuçlarına göre göre uzun ve kısa dönemde yabancı ziyaretçilerden elde edilen gelirlerin iktisadi büyümeyi olumlu etkilediği tespit edilmiştir.

Esen ve Özata (2017), Türkiye'nin 2003Q1-2015Q4 dönemi verileri ile gerçekleştirdikleri araştırmada, turizm sektörünün ekonomik büyüme üzerindeki etkilerini analiz etmişlerdir. Çalışmada ARDL sınır testi ile reel GSYH, reel döviz kuru ve uluslararası turist sayısı verileri kullanılmıştır. Analiz sonuçlarına göre, turizm sektörünün kısa ve uzun dönemde GSYH'yı pozi- 
tif ve anlamlı olarak etkilediği tespit edilmiştir. Ayrıca Toda-Yamamoto nedensellik analizi sonucuna göre, turizm sektöründen ekonomik büyümeye doğru tek yönlü bir nedensellik ilişkisi tespit edilmiştir.

Gövdeli (2018), Türkiye'nin 1963-2015 dönemi verilerini kullanarak ihracat gelirleri, turizmden elde edilen gelirler ve ekonomik büyüme arasındaki ilişkileri araştırmıştır. Maki eşbütünleşme testi sonuçlarına göre seriler eşbütünleşik tespit edilmiştir. Bu bağlamda, serilerin uzun dönemde birlikte hareket edeceği anlaşılmıştır. Nedensellik analizi sonuçlarına göre, ihracat gelirlerinden iktisadi büyümeye ve ihracat gelirlerinden turizm gelirlerine doğru tek yönlü nedensellik bulunmuştur. Ancak turizm gelirleri ile iktisadi büyüme arasında herhangi bir etkileşim tespit edilememiştir.

\subsection{Uluslararası Literatür}

Balaguer ve Jorda (2002), İspanya'nın 1975-1997 dönemi verilerini kullanarak turizm hareketlerinin ekonomik büyümedeki rolünü araştırmıştır. Çalışmada Johansen eşbütünleşme ve Granger nedensellik testleri kullanılmıştır. Analiz sonuçlarına göre, İspanya ekonomik gelişiminin uluslararası turizm hareketlerinden pozitif ve anlamlı bir şekilde etkilendiği tespit edilmiştir.

Dritsakis (2004), Yunanistan'ın reel gayri safi yurtiçi hasıla, uluslararası turizm gelirleri ve reel efektif döviz kuru verilerini kullanarak 1960Q1-2000Q4 dönemi için turizm sektörünün ekonomik büyüme üzerindeki rolünü incelemiştir. Çalışmada nedensellik testi ve vektör otoregresyon (VAR) modeli kullanılmıştır. Analiz sonuçlarına göre, uluslararası turizm gelirleri ve reel gayri safi yurtiçi hasıla arasında uzun dönemli bir Granger nedensellik tespit edilmiştir.

Proenca ve Soukiazis (2008), dört Güney Avrupa ülkesinin 1990-2004 dönemi verilerini kullanarak bir panel veri analizi gerçekleştirmiştir. Analiz sonuçlarına göre, turizm sektörü ülke yaşam standardının gelişimine önemli ölçüde katkıda bulunduğu tespit edilmiştir.

Dritsakis (2012), Akdeniz'de kıyısı bulunan Fransa, Türkiye, İspanya, Yunanistan, İtalya, Güney Kıbrıs ve Tunus'un 1980-2007 dönemi verileri ile turizm hareketleri ve ekonomik büyüme arasındaki ilişkileri araştırmıştır. Çalışmada söz konusu ülkelerin kişi başına reel gayri safi yurtiçi hasıla, reel efektif döviz kuru, kişi başına uluslararası turist sayısı ve kişi başına reel turizm geliri değişkenleri ile heterojen panel eşbütünleşme testleri yapılmıştır. Analiz sonuçlarına göre, turizm hareketleri ile kişi başına reel gayri safi yurtiçi hasıla arasında uzun dönemli panel eş bütünleşme ilişkisi tespit edilmiştir. Uzun dönemli katsayıları belirlemek amacı yapılan FMOLS (Fully Modified OLS) tahminleri, kişi başına reel gayri safi yurtiçi hasıla üzerinde turizm gelirlerinin daha yüksek bir etkisi olduğunu göstermiştir.

Chou (2013), on geçiş ekonomisinde turizm harcamaları ile ekonomik büyüme arasındaki nedensel ilişkileri 1988-2011 dönemi için incelemiştir. Ampirik sonuçlar nedensellik yönüne dair kanıtları desteklemektedir. Ayrıca turizm kaynaklı büyüme hipotezi Güney Kıbrıs, Letonya ve Slovakya için geçerli tespit edilmiştir.

Vanegas (2018), 1960-2016 dönemi için Nikaragua'nın kamu harcamaları, para politikası ve turizm gelirlerinin ekonomik büyüme üzerindeki etkilerini araştırmıştır. Çalışmada ARDL yöntemi uygulanmış ve turizm gelirlerinde $\% 1$ 'lik artışın gayri safi yurtiçi hasılada yaklaşık \%0,29 oranında artış sağladığı görülmüştür. 


\section{Model ve Veri Seti}

Çalışmada turizm sektörünün ekonomik performans üzerindeki etkilerini araştırmak amacıyla 1987-2018 dönemini kapsayan yıllık veriler kullanılmıştır. Bu bağlamda Dünya Bankası veri tabanından ekonomik performansı temsilen reel GSYH ve turizm sektörünü temsilen uluslararası turizm gelirleri alınmıştır. Ayrıca klasik üretim fonksiyonun temel girdilerinden emeği temsil etmek üzere toplam işgücü ve sermayeyi temsil etmek üzere brüt sermaye birikimi kontrol değişken olarak modele eklenmiştir. Tüm veriler logaritmik formda ele alınmıştır. Değişkenlere ait bilgiler Tablo 4'te sunulmuştur.

Tablo 4: Veri Seti

\begin{tabular}{l|l}
\hline \multicolumn{1}{c|}{ Değişkenler } & \multicolumn{1}{c}{ Açıklama } \\
\hline InGSYH & GSYH (Sabit 2010 \$) \\
InK & Gayri Safi Sermaye Birikimi (2010\$) \\
InL & Toplam İşgücü \\
InTREC & Uluslararası Turizm Gelirleri (\$) \\
\hline
\end{tabular}

Tablo 4'te belirtilen değişkenler ışığında model aşağıdaki gibi oluşturulmuştur.

$$
\operatorname{lnGSYH}=\beta_{0}+\beta_{1} \ln K_{t}+\beta_{2} \ln L_{t}+\beta_{3} \ln T R E C_{t}+\mu_{t}
$$

(1) numaralı eşitlikte $\beta_{0}$ sabit, $\beta_{1}, \beta_{2}, \beta_{3}$ tahmin edilecek parametreler ve $\mu^{\prime}$ da hata terimini ifade etmektedir.

Şekil 3: Modelde Kullanılan Değişkenlerin Grafiği

LNGDP

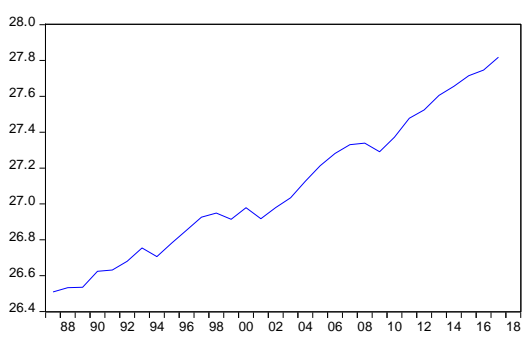

LNL

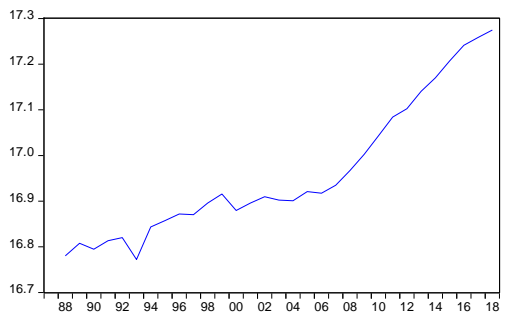

LNK

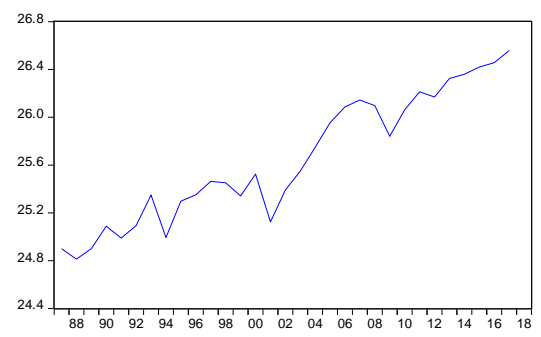

LNTREC

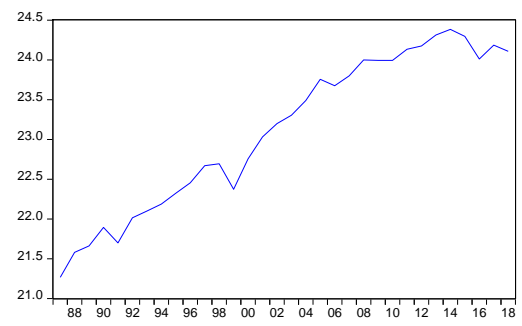

Şekil 3'te modelde kullanılan değişkenlerin grafiklerine yer verilmiştir. Grafikler incelendiğinde değişkenlerin tamamında artan yönlü ve kırılmalı bir yapı gözlenmektedir. Dolayısıyla 
geleneksel birim kök testlerinin yanı sıra yapısal kırılmaya izin veren birim kök testlerinin de kullanılması daha tutarlı analizlerin yapılmasına olanak sağlayacaktır.

\section{Metodoloji ve Bulgular}

Çalışmada öncelikle ADF ve PP birim kök testleri ile yapısal kırılmaya izin veren ZivotAndrews (1992) birim kök testi uygulanmıştır. Serilerin yapısal kırılma olmadan ve yapısal kırılma altında aynı düzeyde durağan olduğu tespit edildikten sonra yapısal kırılmalı Gregory ve Hansen (1996) eşbütünleşme testi yapılmıştır. Seriler arasında uzun dönemli bir eşbütünleşme ilişkisi tespit edildiğinden ARDL modeli genel tahmin sonuçları ile uzun dönem katsayıları belirlenmiştir. Son olarak hata düzeltme modeli ile kısa dönemli araştırma gerçekleştirilerek ampirik analiz sonlandırılmıştır.

\subsection{Birim Kök Testi}

Eşbütünleşme yönteminin kullanıldığı analizlerde yer alan serilerin durağanlık derecesi yöntem seçimi açısından önem arz etmektedir. Serilerin durağanlık derecesine göre farklı testler geliştirilmiştir. Bu çalışmada serilerin durağanlık derecelerini tespit etmek amacıyla Genişletilmiş Dickey-Fuller (1979) ve Philips Perron (1988) birim kök testleri ile yapısal kırılmaya izin veren Zivot-Andrews (1992) birim kök testi kullanılmıştır. Genişletilmiş Dickey-Fuller ve Philips Perron test sonuçları Tablo 5'te görülebilmektedir.

Tablo 5 incelendiğinde modelde yer alan InGSYH, InL ve InTREC'in hem ADF hem de PP birim kök test sonuçlarının sabitli sınamalarında düzeyde durağan olmadıkları gözlenmektedir. Sermayeyi temsil eden InK'nın sabitli ve trendli sınamada düzeyde durağan olduğu tespit edilmiştir. Serilerin birinci farkları alınarak ADF ve PP birim kök testleri uygulandığında ise tümü durağan hale gelmiştir.

Tablo 5: ADF ve PP Birim Kök Testi Sonuçları

\begin{tabular}{|c|c|c|c|c|}
\hline \multirow[b]{3}{*}{ Değişken } & \multicolumn{4}{|c|}{ Düzey Değeri } \\
\hline & \multicolumn{2}{|c|}{ ADF } & \multicolumn{2}{|c|}{ PP } \\
\hline & Sabitli & Sabitli Trendli & Sabitli & Sabitli Trendli \\
\hline InGSYH & $0.765984(0)$ & $-2.107370(0)$ & $2.135974(6)$ & $-2.122861(1)$ \\
\hline InK & $-0.446676(1)$ & $-3.822508 * *(0)$ & $-0.346658(1)$ & $-3.815557^{* *}(1)$ \\
\hline $\operatorname{lnL}$ & $1.485990(0)$ & $-0.799017(0)$ & $1.825622(3)$ & $-0.684652(3)$ \\
\hline \multirow[t]{3}{*}{ InTREC } & $-1.932857(0)$ & $-1.297127(0)$ & $-2.237516(4)$ & $-1.297127(0)$ \\
\hline & \multicolumn{4}{|c|}{$\Delta$ Birinci Fark Değeri } \\
\hline & \multicolumn{2}{|c|}{$A D F$} & \multicolumn{2}{|c|}{ PP } \\
\hline Değişken & Sabitli & Sabitli Trendli & Sabitli & Sabitli Trendli \\
\hline InGSYH & $-5.684067 * * *(0)$ & $-5.789586 * * *(0)$ & $-5.801311 * * *(4)$ & $-7.518524 * * *(6)$ \\
\hline InK & $-7.850792 * * *(0)$ & $-7.706387^{* * *}(0)$ & $-8.034111^{* * *}(2)$ & $-7.882285^{* * *}(2)$ \\
\hline $\ln L$ & $-5.563086 * * *(0)$ & $-6.608365 * * *(0)$ & $-5.635151 * * *(4)$ & $-6.660095 * * *(2)$ \\
\hline InTREC & $-6.349419 * * *(0)$ & $-6.727348 * * *(0)$ & $-6.349419 * * *(0)$ & $-7.032435 * * *(4)$ \\
\hline
\end{tabular}

Not: ADF testi için uygun gecikme uzunluğu AIC kriteri kullanılarak otomatik olarak seçilmiştir. PP testinde BarlettKernel metodu ve Newey-West bant genişliği metodu otomatik olarak seçilmiştir. Parantez içindeki rakamlar PP testinde bant genişliğini, ADF testinde ise optimum gecikme uzunluğunu göstermektedir. $* * *, * *$ sırasıyla $\% 1$ ve $\% 5$ düzeyinde anlamlılı̆ı göstermektedir.

Zivot-Andrews (1992) birim kök testi, yapısal kırılma noktasının içsel tahmin edildiği bir durağanlık testidir. Zivot- Andrews birim kök testi üç yapısal kırılma modeli kurularak yapılmak- 
tadır. Model A sabitte meydana gelen kırılmayı, Model B eğimde meydana gelen kırılmayı ve Model $C$ hem sabit hem de eğimde meydana gelen kırılmayı test etmektedir. Zivot-Andrews birim kök testinde temel hipotez serilerde birim kök olduğunu, alternatif hipotez ise serilerin durağan olduğunu ifade etmektedir. Test sonucu elde edilen $t$ istatistikleri kritik değerlerden mutlak değer olarak küçük tespit edilirse alternatif hipotez-serilerin durağan olduğu hipotezi reddedilmektedir.

Tablo 6'da Zivot-Andrews (1992) birim kök testi sonuçlarına yer verilmiştir. Tablonun ilk bölümünde düzeyde birim kök test sonuçları yer alırken, tablonun alt kısmında değişkenlerin birinci farklarındaki test sonuçları gösterilmiştir.

Tablo 6: Zivot-Andrews (1992) Birim Kök Testi

\begin{tabular}{|c|c|c|c|c|c|c|}
\hline \multirow[t]{2}{*}{ Değişken/Model } & \multicolumn{2}{|c|}{ Model A } & \multicolumn{2}{|c|}{ Model B } & \multicolumn{2}{|c|}{ Model C } \\
\hline & $\mathrm{t}$ & Kırılma & $\mathrm{t}$ & Kırılma & $\mathrm{t}$ & Kırılma \\
\hline InGSYH & -3.64 & 1999 & -3.39 & 2003 & -4.11 & 2001 \\
\hline InK & -4.83 & 2004 & -4.07 & 2002 & -4.85 & 2004 \\
\hline $\operatorname{lnL}$ & -2.37 & 2000 & -4.57 & 2008 & -4.42 & 2006 \\
\hline InTREC & -2.51 & 2001 & -4.18 & 2013 & -4.16 & 2013 \\
\hline \multirow[t]{3}{*}{ Kritik Değerler* } & \multicolumn{2}{|c|}{$-5.34(\% 1)$} & \multicolumn{2}{|c|}{$-4.80(\% 1)$} & \multicolumn{2}{|c|}{$-5.57(\% 1)$} \\
\hline & \multicolumn{2}{|c|}{$-4.93(\% 5)$} & \multicolumn{2}{|c|}{$-4.42(\% 5)$} & \multicolumn{2}{|c|}{$-5.08(\% 5)$} \\
\hline & \multicolumn{2}{|c|}{$-4.58(\% 10)$} & \multicolumn{2}{|c|}{$-4.11(\% 10)$} & \multicolumn{2}{|c|}{$-4.82(\% 10)$} \\
\hline$\Delta \operatorname{lnGSYH}$ & -6.07 & 2003 & -5.74 & 2000 & -5.98 & 2003 \\
\hline$\Delta \operatorname{lnK}$ & -8.37 & 2003 & -7.57 & 2000 & -8.20 & 2003 \\
\hline$\Delta \operatorname{lnL}$ & -7.74 & 2008 & -5.08 & 2008 & -5.71 & 2006 \\
\hline$\triangle \operatorname{lnTREC}$ & -8.12 & 2000 & -7.18 & 2006 & -7.96 & 2000 \\
\hline
\end{tabular}

* Kritik değerler Zivot ve Andrews (1992) çalışmasından elde edilmiştir.

Tablo 6'ya göre Model A'da değişkenlerden elde edilen t istatistikleri kritik değerlerden mutlak değer olarak küçük olduğu için düzeyde durağan olduğu hipotez reddedilir, dolayısıyla değişkende yapısal kırılmalı birim kökün varlığını gösteren temel hipotez kabul edilmektedir. Model C'de ise sadece InK değişkeni \%10 önem düzeyinde mutlak değer olarak büyük tespit edilmiş olup diğer değişkenlerin $t$ istatistikleri kritik değerlerden yine küçüktür. Dolayısıyla yapısal kırılmalı birim kökün varlığını gösteren temel hipotez kabul edilmektedir. Serilerin birinci farkları alınarak test uygulandığında ise tümü durağan hale gelmiştir.

Birim kök testlerinden elde edilen bulgular değişkenlerin düzeyde ve birinci farklarında durağan olduğunu ifade etmektedir. Dolayısıyla sonraki aşamada eşbütünleşme testine geçilebilmektedir.

\subsection{Gregory ve Hansen (1996) Eşbütünleşme Testi}

Çalışmada yapısal kırılmalı analize olanak sağlayan Zivot-Andrews birim kök testinin ardından yine yapısal kırılmayı dikkate alan Gregory ve Hansen (1996) eşbütünleşme testi kullanımıştır. Böylece yapısal kırılma altında seriler arasında uzun dönemli bir ilişkinin varlığı araştırılacaktır. Gregory ve Hansen uzun dönemde seriler arasında bir ilişkinin olup olmadığını analiz etmek amacıyla üç model geliştirmiştir. illk model sabitte kırılma modeli, ikinci model trend ve 
sabitte kırılma modeli ve üçüncü model ise rejim değişikliği modeli olarak adlandırılmaktadır. Tablo 7'de Gregory ve Hansen (1996) eşbütünleşme testi sonuçları gösterilmektedir.

Tablo 7: Gregory ve Hansen (1996) Eşbütünleşme Testi Sonuçları

\begin{tabular}{c|ccccc}
\hline Model & Test Istatistiği & Kırılma Yılı & \multicolumn{3}{c}{ Kritik Değerler* } \\
\cline { 3 - 6 } & & & $\% 1$ & $\% 5$ & $\% 10$ \\
Model 1 & -5.90 & 2007 & -5.77 & -5.28 & -5.02 \\
Model 2 & -6.42 & 2010 & -6.05 & -5.57 & -5.33 \\
Model 3 & -6.23 & 1998 & -6.51 & -6.00 & -5.75 \\
\hline
\end{tabular}

* Kritik değerler Gregory and Hansen (1996) çalışmasından alınmıştır.

Bilgi Kriteri BIC seçilmiştir.

Gregory ve Hansen eşbütünleşme testi sonucu elde edilen istatistik değeri kritik değerlerden büyük olursa eşbütünleşmenin olmadığını ileri süren temel hipotez reddedilmektedir. Tablo 7'de elde edilen sonuçlara göre her üç modelin test istatistiği kritik değerlerden yüksektir. Dolayısıyla uzun dönemde seriler arasında bir eşbütünleşmenin olduğu söylenebilmektedir.

\subsection{ARDL Modeli ve Uzun Dönem Katsayılar}

Değişkenler arasında eşbütünleşme ilişkisi tespit edildiğinden öncelikle ARDL modeli genel tahmin sonuçları ile uzun dönem katsayıları belirlenmiştir. Değişkenler arasındaki uzun dönem ilişkileri belirleyen denklem (3) numaralı eşitlikte gösterilmiştir.

$$
\operatorname{lnGSYH}_{t}=\beta_{0}+\sum_{i: 1}^{m} \beta_{1 i} \operatorname{lnGSYH_{t-i}}+\sum_{i: 0}^{k} \beta_{2 i} \ln K_{t-i}+\sum_{i: 0}^{p} \beta_{3 i} \ln L_{t-i}+\sum_{i: 0}^{n} \beta_{4 i} \ln T R E C_{t-i}+\varepsilon_{t}(3)
$$

Tablo 8'de ise 3 numaralı eşitlik çerçevesinde uygun gecikme yapısına sahip ARDL modeli tahmin sonuçları ve modelle ilgili tanısal test sonuçlarına yer verilmiştir.

Tablo 8: ARDL (2,2,2,0) Modeli Uzun Dönem Tahmin Sonuçları ve Tanısal Test Sonuçları

\begin{tabular}{|c|c|c|c|}
\hline \multicolumn{4}{|c|}{ ARDL $(2,2,2,0)$ Modeli Tahmin Sonuçları } \\
\hline Değişkenler & Katsayı & Standart Hata & t istatistiği \\
\hline $\operatorname{lnGDP}(-1)$ & $0.387092^{* * *}$ & 0.091039 & 4.251947 \\
\hline $\ln G D P(-2)$ & $-0.115460 *$ & 0.064482 & -1.790582 \\
\hline InK & $0.266942 * * *$ & 0.010729 & 24.88001 \\
\hline $\operatorname{lnK}(-1)$ & -0.041843 & 0.025326 & -1.652171 \\
\hline $\operatorname{lnK}(-2)$ & 0.029778 & 0.019374 & 1.536968 \\
\hline $\operatorname{lnL}$ & $0.258750 * * *$ & 0.064289 & 4.024765 \\
\hline $\operatorname{lnL}(-1)$ & 0.093469 & 0.097038 & 0.963216 \\
\hline $\operatorname{lnL}(-2)$ & $0.427336 * * *$ & 0.084071 & 5.083063 \\
\hline InTREC & $0.059351^{* * *}$ & 0.006848 & 8.666327 \\
\hline C & $-1.360599 * * *$ & 0.276436 & -4.921928 \\
\hline \multicolumn{4}{|c|}{ Test ve Tanısal Test Sonuçları } \\
\hline$R^{2}$ & 0.99 & $X_{B G}^{2}$ & $0.346218(0.7125)$ \\
\hline$\overline{R^{2}}$ & 0.99 & $X_{J B}^{2}$ & $1.380261(0.501510)$ \\
\hline F İstatistiği & $11554.40^{* * *}$ & $X_{A R C H}^{2}$ & $1.306553(0.2901)$ \\
\hline DW İstatistiği & 1.936128 & $X_{R A M S E Y}^{2}$ & $1.509323(0.1496)$ \\
\hline
\end{tabular}

Modelde otokorelasyon sorunu tespiti amacı ile Breusch-Godfrey LM testi $\left(X_{B G}^{2}\right)$, normallik için Jarque-Bera testi $\left(X_{J B}^{2}\right)$, değişen varyans sorunu tespiti amacı ile ARCH testi $\left(X_{A R C H}^{2}\right)$ ve model belirleme hatası tespiti amacı ile Ramsey RESET testi $\left(X_{R A M S E Y}^{2}\right)$ uygulanmıştır. Parantez içindeki değerler olasılık değerlerini göstermektedir. 
$* * * \% 1, * * \% 5, * \% 10$ düzeyinde anlamlı test sonuçlarını ifade etmektedir.

Tanısal test sonuçlarına göre modelde otokorelasyon, normallik ve değişen varyans açısından bir sorun tespit edilmemiştir. Tahmin edilen modelin istikrarlığını belirlemek amacıyla Brown vd. (1975) tarafından literatüre kazandırılan CUSUM ve CUSUMSQ testleri kullanılmıştır. CUSUM ve CUSUMSQ testlerinde yer alan istatistikler ardışık olarak yinelenmekte ve kırımaların yer aldığı noktalara karşı işaretlenmektedir. Yinelemeli parametre tahminlerinden elde edilen grafiklerin incelenmesi ile yapısal kırılmanın varlığı ya da söz konusu modelin istikrarlı olup olmadığı konusunda yorum yapılabilmektedir. CUSUM ve CUSUMSQ test istatistikleri $\% 5$ anlam düzeyinde belirlenen çizgiler arasında yer alıyorsa ARDL modeli katsayılarının istikrarlı olduğu söylenebilmektedir (Esen ve Özata, 2015: 49). Şekil 3'te CUSUM ve CUSUMSQ istatistiklerine ait grafikler gösterilmiştir. Şekillerde görüldüğü üzere uzun dönem modeline ilişkin CUSUM ve CUSUMSQ testi istatistikleri \%5 anlamlılık düzeyinde belirlene çizgiler arasında yer almaktadır. Dolayısıyla ARDL modelinin istikrarlı olduğu konusunda karara varılabilmektedir.

Şekil 4: CUSUM ve CUSUMSQ istatistikleri Grafikleri
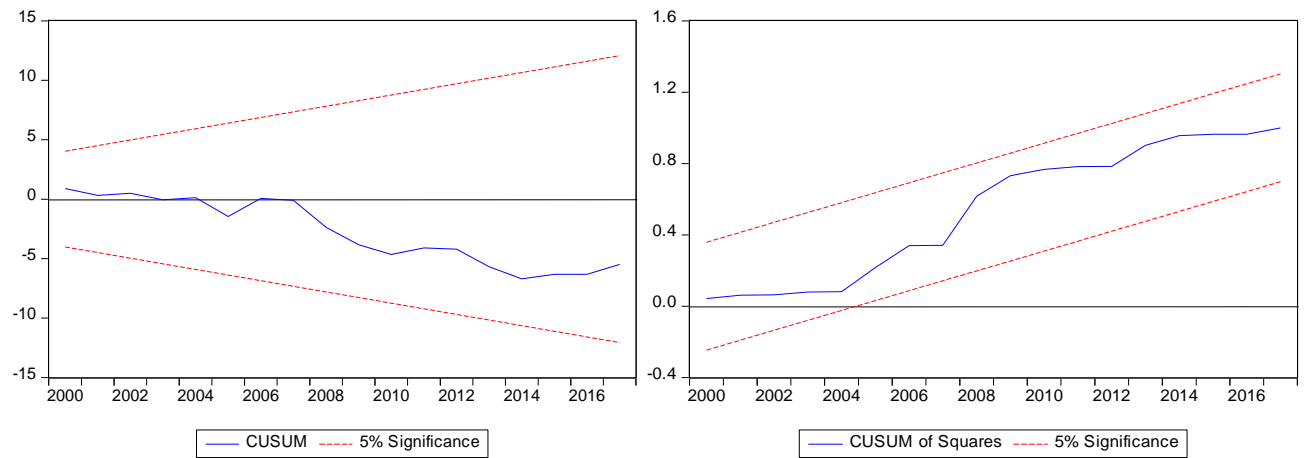

Sonraki aşamada ARDL $(2,2,2,0)$ modeli çerçevesinde uzun dönem katsayıların belirlenmesine geçilmiştir. Tablo 9'da modelin uzun dönem katsayılarına yer verilmiştir. Sonuçlara göre, işgücü, sermaye ve turizm gelirlerini ifade eden değişkenlerin tamamı istatiksel olarak pozitif ve anlamlı tespit edilmiştir. Çalışmada kullanılan değişkenler açısından ilgili dönemde Türkiye'de ekonomik performansa etki açısından en büyük katkıyı klasik üretim faktörlerinden işgücü (1.07) yaparken onu sermaye (0.34) izlemiştir. Turizm gelirleri (0.08) ise işgücü ve sermayenin ardından gelmektedir.

Tablo 9:ARDL (2,2,2,0) Modeli Uzun Dönem Katsayıları

\begin{tabular}{l|ccc}
\hline \multicolumn{4}{c}{ Uzun Dönem Katsayıları } \\
\hline Değişkenler & Katsayı & Standart Hata & t istatistiği \\
InK & $0.349928^{* * *}$ & 0.014613 & 23.94608 \\
InL & $1.070274^{* * *}$ & 0.032866 & 32.56522 \\
InTREC & $0.081485^{* * *}$ & 0.005916 & 13.77398 \\
C & $-1.868009^{* * *}$ & 0.380864 & -4.904661 \\
\hline
\end{tabular}

$* * * \% 1, * * \% 5, * \% 10$ düzeyinde anlamlı test sonuçlarını ifade etmektedir. 


\subsection{Hata Düzeltme Modeli}

Seriler arasında olası kısa dönemli etkileşimler (4) numaralı eşitlik bazında ele alınarak, ARDL kısıtsız hata düzeltme modeli çerçevesinde incelenmiştir.

$$
\begin{aligned}
\Delta \operatorname{lnGSYH} H_{t}=\beta_{0}+ & \beta_{1} E C M_{t-1}+\sum_{i: 1}^{m} \beta_{2} \Delta \operatorname{lnGSYH_{t-i}}+\sum_{i: 0}^{k} \beta_{3} \Delta \ln K_{t-i}+\sum_{i: 0}^{p} \beta_{4} \Delta \ln L_{t-i} \\
& +\sum_{i: 0}^{n} \beta_{5} \Delta \ln T R E C_{t-i}+\varepsilon_{t}
\end{aligned}
$$

Denklemde yer alan $E C M_{t-1}$ hata teriminin bir dönem gecikmeli değerini göstermektedir. Elde edilen katsayı, kısa dönemde gerçekleşen dengesizliğin ne kadar sürede giderileceğini belirlemek için kullanılmaktadır. Söz konusu katsayının negatif ve istatistiki olarak anlamlı çıkması sistemin dalgalanarak dengeye geldiğini göstermektedir.

Tablo 10 'da hata teriminin ve diğer değişkenlerin kısa dönem katsayılarına yer verilmiştir.

Tablo 10 : ARDL $(2,1,2,0)$ Hata Düzeltme Modeli Tahmin Sonuçları

\begin{tabular}{l|ccc}
\hline Değişkenler & Katsayı & Standart Hata & t istatistiği \\
\hline D(LNGDP(-1)) & 0.141535 & 0.115842 & 1.221786 \\
D(LNGDP(-2)) & 0.062941 & 0.047956 & 1.312470 \\
D(LNK) & $0.261844 * * *$ & 0.011805 & 22.18141 \\
D(LNK(-1)) & -0.003620 & 0.032034 & -0.112996 \\
D(LNL) & $0.306920^{* * *}$ & 0.075497 & 4.065331 \\
D(LNL(-1)) & -0.059657 & 0.098306 & -0.606854 \\
D(LNL(-2)) & $0.3166556^{* * *}$ & 0.081196 & 3.899906 \\
D(LNTREC) & $0.058291^{* * *}$ & 0.010225 & 5.700763 \\
C & 0.006969 & 0.004154 & 1.677842 \\
ECM(-1) & $-0.374545^{* *}$ & 0.140049 & -2.674390 \\
\hline
\end{tabular}

*** \%1, **\%5, *\%10 düzeyinde anlamlı test sonuçlarını ifade etmektedir.

Tablo 10'daki değişkenlerin katsayıları incelendiğinde uzun dönem analizine benzer şekilde tüm değişkenler istatistiki olarak pozitif ve anlamlı bulunmuştur. Ayrıca hata terimi ECM'de istatistiki olarak anlamlı ve katsayısı negatif tespit edilmiştir. Bu durum değişkenler arasında kısa dönemde meydana gelen dengesizliklerin uzun dönemde ortadan kalkarak dengenin tekrar sağlandığını ortaya koymaktadır (Narayan ve Smyth, 2006: 339).

\section{Sonuç}

Turizm, sanayi sektörü açısından geri kalmış ve döviz açığı bulunan ülkeler açısından son derece önemli bir sektördür. Bacasız sanayi olarak da adlandırılan sektör, aynı zamanda birçok alt sektörü ilgilendiren faaliyetleri bünyesinde barındırmaktadır. Böylece sadece cari açık sorunu değil düşük büyüme hızı, işsizlik, talep yetersizliği, düşük milli gelir gibi ekonomik sorunlara olumlu katkılarda bulunmaktadır.

Bu çalışmada önemli bir turizm potansiyeli olan ve yıllardır cari açık sorunu ile uğraşan Türkiye'nin turizm gelirleri ile ekonomik performansı arasındaki ilişki araştırılmıştır. Bu bağlamda Türkiye'nin 1987-2018 dönemine ait verileri ile bir analiz gerçekleştirilmiştir. Çalışmada turizm gelirlerinin yanı sıra en önemli üretim faktörleri olan işgücü ve sermayeyi temsil eden kontrol değişkenler kullanılmıştır. Bu açıdan çalışma, daha önce yapılan çalışmalardan ayrılmaktadır. Analizde öncelikli olarak ADF ve PP testleri ile değişkenlerin durağanlık kontrolleri 
yapılmıştır. Ayrıca yapısal kırılma altında birim kök varlığının araştırılması amacıyla Zivot ve Andrews (1992) testi gerçekleştirilmiştir. Birim kök testleri sonucu değişkenlerin I(0) ve I(1)'de durağan oldukları tespit edildikten sonra eşbütünleşme testine geçilmiştir. Yapısal kırılmaya izin veren Gregory ve Hansen (1996) eşbütünleşme testi sonucu değişkenler arasında eşbütünleşme ilişkisi tespit edilmiş ve uzun-kısa dönemli ilişkilerin araştırılması için ARDL modeline geçilmiştir.

Uzun dönemde emeğin katsayısı 1,07, sermayenin katsayısı 0,34 ve turizm gelirlerinin katsayısı 0,08 olarak tespit edilmiştir. Değişkenler literatürle uyumlu olarak pozitif ve anlamlı çıkması turizmin ekonomik performansa katkılarını bir kez daha ön plana çıkarmıştır. Kısa dönemde ise hata düzeltme katsayısı $-0,37$ ve istatistiki olarak anlamlı bulunmuştur. Bu sonuç değişkenler arasında uzun dönem dengesinden bir sapma olması halinde tekrar dengeye gelineceğini göstermiştir. Çalışmada elde edilen sonuçlar Balaguer ve Jorda (2002), Sugiyarto vd. (2003), Durbarry (2004), Croes ve Vanegas (2008), Proenca ve Soukiazis (2008), Fayissa vd. (2011), Dritsakis (2012), Eeckels vd. (2012), Ivanov ve Webster (2013), Surugiu ve Surugiu (2013), Brida vd. (2016) ile benzerlik göstermiş ve turizme dayalı büyüme hipotezini (TLEG) destekleyen kanıtlar ortaya koymuştur.

Turizm ekonomik olarak ülkelere büyük faydalar sağlamaktadır. Ancak bir ülkenin veya ülkenin belli bir bölgesinin kaynaklarını sadece turizm faaliyetlerine ayırması beraberinde bazı sakıncalarda getirmektedir. 2015 yılında Rus uçağının düşürülmesi olayından sonra yaşananlar ülke turizm sektörü açısından zor zamanların yaşanmasına neden olmuştur. Birçok otel, pansiyon vb. işletme kapanma noktasına gelirken istihdam olumsuz olarak etkilenmiştir. Turizm bu tür krizlerden etkilenen sektörlerin başında geldiğinden turizm bölgesinde alternatif sektörlerin oluşturulması önem arz etmektedir. Ayrıca gelir düzeyi düşük ve harcama yapmayan çok sayıda yabancı ziyaretçilerden ziyade gelir düzeyi yüksek yabancı ziyaretçileri ülkeye çekmek daha faydalı olacaktır. Sadece deniz, kum, güneş paketleri değil sağlık, kültür, kongre ve doğa turizm paketleri ile farklı ülkelerden yabancı ziyaretçi ağırlamak krizlerin etkisini azaltabilecektir. Böylece turizmin ekonomide yarattığı katma değerin daha fazla olacağı ve diğer sektörlere kaynak yaratan etkisinin büyüyeceği düşünülmektedir.

Turizm sektörü dinamik bir sektör olmakla beraber talep elastikiyeti son derece yüksektir. Bu bağlamda ekonomik kriz, savaş, doğal afet gibi olumsuz gelişmelerden ilk etkilenen sektörlerin başında gelmektedir. Türkiye gibi gelişmekte olan ülkelerin bu durumu göz önünde bulundurmak suretiyle politikalar uygulaması daha sağlıklı olacaktır. 


\section{Eskişehir Osmangazi Üniversitesi IïBF Dergisi}

\section{Kaynaklar}

Antonakakis, Nikolaos; Dragouni, Mina; Filis, George (2015), “How Strong is The Linkage Between Tourism and Economic Growth in Europe?", Economic Modelling, Vol. 44 (2015): 142-155.

Apergis, Nicholas; Payne, E. James (2012), "Tourism and Growth in the Caribbean. Evidence from a Panel Error Correction Model. Tourism Economics, Vol. 18, No. 4, 449-456.

Bahar, Ozan (2006), “Turizm Sektörünün Türkiye'nin Ekonomik Büyümesi Üzerindeki Etkisi: VAR Analizi Yaklasımı”. Yönetim ve Ekonomi, C. 13, S. 2: 137-150.

Balaguer, Jacint; Cantavella-Jordá, Manuel (2002), 'Tourism as a Long-Run Economic Growth Factor: The Spanish Case', Applied Economics, Vol. 34, No. 7: 877-884.

Brida, J. Gabriel; Lanzilotta, Bibiana; Pizzolon, Fiorella (2016), "Dynamic Relationship Between Tourism and Economic Growth in MERCOSUR Countries: A Nonlinear Approach Based on Asymmetric Time Series Models", Economics Bulletin, Vol. 36, No. 2 , 879-894.

Brown, R.L.; Durbin, J.; Evans, J.M. (1975), "Techniques for Testing The Constancy of Regression Relations Over Time”, Journal of the Royal Statistical Society, Vol. 37, No.2: 149-163.

Chatziantoniou, Ioannis; Filis, George; Eeckels, Bruno; Alexandros, Apostolakis (2003), Oil Prices, Tourism Income and Economic Growth: A Structural VAR Approach for European Mediterranean Countries, Tourism Management, Vol. 36 (2013): 331-341.

Chen, Ching; Song Zan, Chiou-Wei, (2009), Tourism Expansion, Tourism Uncertainty and Economic Growth: New Evidence from Taiwan and Korea, Tourism Management, Vol. 30, No. 6, 812-818.

Chou, Ming Che (2013), "Does Tourism Development Promote Economic Growth in Transition Countries? A Panel Data Analysis", Economic Modelling, Vol. 33: 226-232.

Cortés-Jiménez, Isabel; Pulina, Manuela; Prunera, Carme Riera; Artis, Manuel (2009), "Tourism and Exports as a Means of Growth", Research Institute of Applied Economics, Working Papers 2009/10.

Croes, Robertico; Vanegas, Manuel (2008). "Cointegration and Causality between Tourism and Poverty Reduction", Journal of Travel Research, Vol. 47, No. 1, 94-103.

Çetintaş, Hakan; Bektaş, Çetin (2008) "Türkiye'de Turizm ve Ekonomik Büyüme Arasındaki Kısa ve Uzun Dönemli İlişkiler", Anatolia: Turizm Araştırmaları Dergisi, C. 19, S.1: 1-8.

Dickey, David; Fuller, Wayne (1979), "Distribution of the Estimators for Autoregressive Time Series With a Unit Root", Journal of American Statistical Association, Vol. 74, No. 366: 427-431.

Dritsakis, Nikolaos (2004), "Tourism as a Long-Run Economic Growth Factor: An Empirical Investigation for Greece Using Causality Analysis", Tourism Economics, V.10, No.3: 305-316.

Dritsakis, Nikolaos (2012). "Tourism Development and Economic Growth in Seven Mediterranean Countries: A Panel Data Approach", Tourism Economics, Vol. 18, No.4: 801-816.

Durbarry, Ramesh (2004), "Tourism and Economic Growth: The Case of Mauritius”, Tourism Economics, Vol. 10, No. 4, 389-401.

Eeckels, Bruno; Filis, George; Leon, Costas (2012), "Tourism Income and Economic Growth in Greece: Empirical Evidence from Their Cyclical Components", Tourism Economics, Vol. 18, No. 4, 817-834.

Eralp, Ziya (1983), Genel Turizm, Ankara: Ankara Üniversitesi Basın Yayın Yüksek Okulu Yayınları.

Esen, Ethem; Özata, Erkan (2017), "Turizmin Ekonomik Büyümeye Etkisi: Turizme Dayalı Büyüme Hipotezinin Türkiye İçin Geçerliğinin ARDL Modeli ile Analizi”, Anadolu Üniversitesi Sosyal Bilimler Dergisi, C.17, S. 1: 43-58.

Eugenio-Martín, Juan Luis; Morales, Noelia Martín; Scarpa, Riccardo (2004), "Tourism and Economic Growth in Latin American countries: A Panel Data Approach", Fondazione Eni Enrico Mattei Working Paper Series, Working Note, 26.

Fayissa, Bichaka; Nsiah, Christian; Tadesse, Bedassa (2011), "Tourism and Economic Growth in Latin American Countries- Further Empirical Evidence", Tourism Economics, Vol. 17, No. 6, 1365-1373.

Gövdeli, Tuncer (2018), “Türkiye'de Turizm, İhracat ve Ekonomik Büyüme illişkisi: Maki Eşbütünleşme ve Bootstrap Nedensellik Analizi”, Bingöl Üniversitesi Sosyal Bilimler Enstitüsü Dergisi, C. 8, S. 16: 571-586.

Gregory, Allan W; Hansen, Bruce E. (1996), "Residual-Based Tests for Cointegration in Models With Regime Shifts" Journal of Econometrics, Vol. 70, No. 1, 99-126. 
Gündüz, Lokman; Hatemi, Abdulnasser (2005), "Is the Tourism-led Growth Hypothesis Valid for Turkey", Applied Economics, Vol. 12, No. 8: 499-504.

Hepaktan, Erdem; Serkan, Çınar (2010), “Turizm Sektörünün Türkiye Ekonomisi Üzerindeki Etkileri”, Celal Bayar Üniversitesi S.B.E. Sosyal Bilimler Dergisi, C. 8, S. 2: 135-154.

Işık, Cem (2010), “Türkiye'de Yabancı Ziyaretçi Harcaması ve Turizm Gelirleri İlişkisi: Bir Eş-bütünleşme Analizi (19702008)", Sosyo-Ekonomi, C. 2010, S. 2: 115-128.

Ivanov, Stanislav; Webster, Craig (2013), "Tourism's Impact on Growth: The Role of Globalisation", Annals of Tourism Research. Vol. 41, 231-236.

Kasimati, Evangelia (2011), “Economic Impact of Tourism on Greece's Economy: Cointegration and Causality Analysis", International Research Journal of Finance and Economics, Vol. 79, 79-85.

Katırcıoğlu, S. Turan (2009) "Revisiting the Tourism-led-growth Hypothesis for Turkey Using the Bounds Test and Johansen Approach for Cointegration" Tourism Management, Vol. 30, 17-20.

Kızılgöl, Özlem; Erbaykal, Erman (2008), “Türkiye'de Turizm Gelirleri ile Ekonomik Büyüme İlişkisi: Bir Nedensellik Analizi", Süleyman Demirel Üniversitesi Iktisadi ve Idari Bilimler Fakültesi Dergisi, C. 13, S. 2: 351-360.

Kozak, Nazmi (2012), Genel Turizm Bilgisi, Eskişehir; T.C. Anadolu Üniversitesi Yayını No: 2472, Açıköğretim Fakültesi Yayını No: 1443.

Narayan, Paresh Kumar (2004), "Fiji's Tourism Demand: The Ardl Approach to Cointegration", Tourism Economics, Vol. 10, No. 2, 193-206.

Narayan, Paresh Kumar; Russell Smyth (2006), "What Determines Migration Flows From Low-Income to High-Income Countries? An Empirical İnvestigation of Fiji-U.S. Migration 1972-2001", Contemporary Economic Policy, Vol. 24, No. 2: 332-342.

Khoshnevis S. Yazdi; Salehi, K. Homa; Soheilzad, Mahshid (2017), "The Relationship Between Tourism, Foreign Direct Investment And Economic Growth: Evidence From Iran", Current Issues in Tourism, Vol. 20, No. 1, 15-26

Kızılkaya, Oktay; Sofuoğlu, Emrah; Karaçor, Zeynep (2016), “Türkiye'de Turizm Gelirleri-Ekonomik Büyüme İlişkisi: ARDL Sınır Testi Yaklaşımı”, Yönetim ve Ekonomi Dergisi, C. 23, S. 1: 203-215.

Lee, Chien-Chiang; Chang, Chun-Ping (2008), "Tourism Development and Economic Growth: A Closer Look at Panels", Tourism Management, Vol. 29, 180-192.

Oh, Chi-Ok (2005), "The Contribution of Tourism Development to Economic Growth in the Korean Economy", Tourism Management, Vol. 26, No. 1, 39-44.

Ongan, Serdar; Demiroz, M., Dündar (2005), "The Contribution of Tourism to The Long-Run Turkish Economic Growth", Journal of Economics, Vol. 53, No. 9: 880-894.

Payne, E. James; Mervar, Andrea (2010), "The Tourism-Growth Nexus in Croatia”. Tourism Economics, Vol. 16, No. 4, 1089-1094.

Phillips, C.B. Peter, Perron, Pierre (1988), "Testing for a Unit Root in Time Series Regression”. Biomètrika, Vol. 75, No.2: 336-346.

Po, Wan-Chen; Huang, Bwo-Nung (2008), "Tourism Development and Economic Growth: A Nonlinear Approach", Physica A: Statistical Mechanics and its Applications, Elsevier, V. 387, No. 22, 5535-5542.

Polat, Esra; Günay, Süleyman (2012), "Türkiye'de Turizm ve Ihracat Gelirlerinin Ekonomik Büyüme Üzerindeki Etkisinin Testi: Eşbütünleşme ve Nedensellik Analizi”, Süleyman Demirel Üniversitesi F.B.E. Dergisi, C. 16, S.2: $204-211$.

Proença, Sara; Soukiazi, Elias (2008), "Tourism as an Economic Growth Factor: A Case Study for Southern European Countries", Tourism Economics, Vol. 14, S. 4: 791-806.

Seetanah, Boopen (2011), "Assessing the Dynamic Economic Impact of Tourism for Island Economies", Annals of Tourism Research, Vol. 38, No. 1, 291-308.

Sugiyarto, Guntur; Blake, Adam; Sinclair, Thea (2003), "Tourism and Globalization Economic İmpact in İndonesia", Annals of Tourism Research, Vol. 30, No. 3, 683-701.

Surugiu, Camelia; Surugiu, M.Razvan (2013), "Is The Tourism Sector Supportive of Economic Growth? Empirical Evidence on Romanian Tourism", Tourism Economics, Vol. 19, No. 1, 115-132.

Tang, Chun-Hung Hugo; Jang, , SooCheong Shawn (2009), "The Tourism-Economy Causality in the United States: A Sub-Industry Level Examination", Tourism Management, Vol. 30, 553-558. 


\section{Eskişehir Osmangazi Üniversitesi IïB Dergisi}

Tang, C. Foon (2011), "Is the Tourism-Led Growth Hypothesis Valid for Malaysia? A View from Disaggregated Tourism Markets", International Journal of Tourism Research, Vol. 13, No. 1, 97-101.

Tuğcu, Can Tağsel (2014), "Tourism and Economic Growth Nexus Revisited: A Panel Causality Analysis for the Case of the Mediterranean Region", Tourism Management, Vol. 42, 207-212.

Vanegas, Manuel (2018), “Tourism, Macroeconomics, Growth, and the St. Louis Equation”, Tourism Review International, Vol.22: 3-21.

Yavuz Nilgün Çil (2006), "Türkiye'de Turizm Gelirlerinin Ekonomik Büyümeye Etkisinin Testi: Yapısal Kırılma ve Nedensellik Analizi”, Doğuş Üniversitesi Dergisi, C. 7, S. 2: 162-171.

Yıldııım, Jülide; Öcal, Nadir, (2004), "Tourism and Economic Growth in Turkey”, Ekonomik Yaklaşım, C. 15, S.52-53: 131-141.

World Tourism Organisation, (UNWTO), (2011), Tourism Towards 2030, Rebublic Of Korea.

World Tourism Organisation (UNWTO), Why Tourism? http://www2.unwto.org/content/why-tourism (Erişim: 21.03.2019).

Zivot, Eric; Andrews, Donald W.K., (1992), "Further Evidence on the Great Crash, The Oil-Price Shock and the UnitRoot Hypothesis", Journal of Business \& Economic Statistic, Vol. 10, No. 3, 251-270. 


\section{The Impacts of Tourism Revenues on Economic Growth: Unit Root and Cointegration Tests with Structural Break for Turkey}

Tourism sector has directly and indirectly positive effects on economies through contribution to economic growth as well as social and cultural development. Tourism demand, both domestic and international, is directly related to income levels, and therefore has prospered as global wealth has increased. Also, tourism development has resulted in a wide range of social and structural transformations of tourism destinations. Tourism is a significant economic strength that make a big contribution to national income, employment, balance of payments, foreign exchange and tax revenues. One of the reasons that the tourism sector stands out economically is that it includes many sub-services. The fact that it affects many sub-sectors such as accommodation, travel, transportation, food and beverage, travel agencies, tour companies, handicrafts and souvenir production increase the importance of tourism. Sector has become one of the principal sectors in international commerce and represents at the same time one of the main income sources for many developing countries. For many developing countries, tourism is one of the main sources of foreign exchange income and the number one export category, creating much needed employment and opportunities for development. Many developing countries including Turkey purpose achieve sustainable economic development through tourism. Turkey is one of the fastest growing countries in the world for tourism industry. In 2018, Turkey is fourth in Europe and third in the Mediterranean region for international arrivals. It is also among the top 15 countries in the world in terms of international tourism revenues. International foreign tourist arrivals to Turkey have grown significantly over the last two years. In 2018, foreign tourist arrivals increased nearly 22 percent from the previous year to 39.45 million. Tourism revenues overall show an increase, as does the number of tourist arrivals. Tourism revenues increased nearly 12 percent from the previous year to 29.50 billion dollars. Also, according to a long term forecast by the "T.R. Ministry of Culture and Tourism" international tourist arrivals will reach 75 million by 2023.

The relationship between tourism and economic performance has been discussed extensively in the previous literature on developed and developing countries. Also, there are many studies in the literature examining the economic effects of tourism in Turkey. In this study, different from other studies, the control variables representing labor and capital, which are the main inputs of the classical production function as well as tourism revenues, were added to the model and the analysis was expanded. In this context, it is thought to contribute to the literature. There are some limitations in the empirical application section of the study. The data subject to analysis covers the period 1998-2017 on an annual basis. The fact that the time interval and consequently the number of observations remain limited is due to the fact that some data were not available in the years before 1998. The real gross domestic product, which is determined as a dependent variable in the empirical research, is considered at the logarithmic level and is interpreted economic performance.

The aim of this study is to examine the relationship between tourism revenues and economic performance, using data from Turkey 1987-2018. For this purpose, structural break unit root and cointegration tests were used. Also, the effects of tourism revenues on economic performance were investigated using ARDL model and Error Correction Model. A structural break may be the change or transition in the time series as a result of some substantial event. Not including the structural breaks into the analysis, in time series analysis, may cause the unit root and cointegration tests to give incorrect results. These results decrease the power of the test used. To this end, this study utilized the unit root test developed by Zivot and Andrews. Afterwards, The Gregory and Hansen cointegration tests applied to test the possible endogenous structural breaks in the data series and the underlying cointegration relationship among the variables. As a result of unit root test, it was determined that the series include unit root in their level values and observed that they become stationary when their first differences are taken. Whether there is a long-term relationship among the variables was searched through Gregory-Hansen structural break cointegration test. According to the results of Gregory- Hansen cointegration test, it can be said that there is a long-term cointegration relationship between tourism revenues and real gross domestic product. According to the long-term estimation results, tourism revenues have a positive impact on economic performance. According to the results of the error correction model, a significant relationship was found between tourism revenues and all other variables. In the long term, the coefficient of labor was determined as 1.07 , the coefficient of capital 0.34 and the coefficient of tourism revenues 0.08. In this context, it has been determined that an increase by one unit in tourism revenues raised the real gross domestic product by 0.08 unit. Results found out in this study and other studies using similar variables and model (Balaguer and Jorda; 2002, Sugiyarto ie.; 2003, Durbarry; 2004, Croes ve Vanegas; 2008, Proenca and Soukiazis; 2008, Fayissa ie.; 2011, Dritsakis; 2012, Eeckels ie. 2012, Ivanov and Webster; 2013, Surugiu and Surugiu; 2013, Brida ie.; 2016) show congruity with the literature. 
Eskişehir Osmangazi Üniversitesi IißBF Dergisi 